\title{
Bactericidal and Sporicidal Activities against Pathogenic Bacteria of Direct Flow Electrolyzed Water
}

\author{
Kataoka $\mathrm{Y}^{1 *}$, Ochi $\mathrm{H}^{1}$, Sawada $\mathrm{T}^{1}$, Miyakawa $\mathrm{Y}^{2}$ and Hatakeyama $\mathrm{H}^{3}$ \\ ${ }^{1}$ Department of Veterinary Microbiology, Nippon Veterinary and Animal Science University, Tokyo 180-8602, Japan \\ ${ }^{2}$ Department of Laboratory Animals, Tokyo Women's Medical University, Tokyo 162-8666, Japan \\ ${ }^{3}$ Department of Biology, Nippon Veterinary and Animal Science University, Tokyo 180-8602, Japan
}

\begin{abstract}
The purpose of this investigation was to examine the bactericidal activity of long lifetime ozone water (LLO water) against pathogenic bacteria of medical, veterinary, and public health interest. An electrolytic system using Pt mesh electrodes combined with a conventional polymer electrolyte, the Nafion 117 membrane, produced LLO water from tap water with high efficiency. LLO water killed 7.144 $\pm 0.0507 \log _{10}$ CFU of Escherichia coli O157:H7, $6.979 \pm 0.045 \log _{10}$ CFU of methicillin-resistant Staphylococcus aureus, $6.503 \pm 0.3681 \log _{10}$ CFU of Pseudomonas aeruginosa and $6.579 \pm 0.123 \log _{10}$ CFU of Legionella pneumophila within one minute. In contrast, endospores of Bacillus anthracis were killed within 20 min. Results of observation of the bactericidal activity of LLO by using an electron microscope, it was revealed that LLO water was shown the bactericidal action by swelling and destroying on the cell wall of the bacterial cells. Our studies demonstrated that LLO water has the potential to be widely applicable in food hygiene, medicine and veterinary medicine as a sterilizing agent. This is the first study to demonstrate the bactericidal activity and characteristics of LLO water.
\end{abstract}

Keywords: Bactericidal activity; Sporicidal activity; Long lifetime ozone water

\section{Introduction}

Functional water produced by electric systems, such as electrolyzed water, has been widely used as a safe and low cost bactericidal water compared with disinfectants. Bactericidal electrolyzed waters, which consist of acidic and alkaline water, are usually produced by addition of $0.1 \% \mathrm{NaCl}$. However, if strong acidic electrolyzed water or a strong alkali electrolytic water is generated, those that contain few amount of sodium hypochlorite $(\mathrm{NaClO})$ as one of the disinfectant [1]. We have developed a new electrolytic water generated by the system to direct electrolysis of tap water [2]. This electrolyzed water, named long-lifetime ozone water (LLO water), has a neutral $\mathrm{pH}$ and contains high concentrations of ozone and hydroxyl radicals, without $\mathrm{NaClO}$ [2]. Hydroxyl radicals produced by the decomposition of ozone water are one of the strongest oxidizers. Ozone can be used instead of chlorine as an effective water disinfectant and is able to inactivate many human pathogenic bacteria which are Bacillus cereus, Escherichia coli, Legionella pneumophila, Mycobacterium fortuitum, Pseudomonas fluorescens, Salmonella Enteritidis, S. Typhimurium and Staphylococcus aureus [3]. However, some protozoa, fungi and spores require a longer time of contact with ozone than bacteria and viruses [3-6]. The LLO water is long-lifetime ozone water; therefore, it is possible to inactivate many pathogenic agents of medicine, veterinary medicine and public health concern.

In the medical science, major etiological agents of nosocomial infections include methicillin-resistant $S$. aureus (MRSA), multidrugresistant $P$. aeruginosa (MDRP) and L. pneumophila [7-9]. These organisms are particularly problematic because of their ubiquitous nature, ability to survive in the hospital environment, and innate resistance to many antibiotics and antiseptics. Bacillus anthracis is a highly pathogenic bacterium that causes anthrax and has been associated with deliberate contamination events [10]. Other Bacillus spp., $B$. cereus and B. subtilis, are endosporeformers that are widespread in the environment. There is the possibility that long-term use of disinfectants to eliminate these causative agents of nosocomical infections can result in environmental pollution. In contrast, electrolyzed water with bactericidal activity eventually changes into water with the passage of time. Stevenson et al. reported that the effect of storage of electrolyzed oxidizing (EO) water [11]. In their results, when stored in the dark, bactericidal efficacy was retained for at least $180 \mathrm{hrs}$. Therefore, electrolyzed water can be applied to clean up the environment in the hospital as well as the environmental pollution caused by bioterrorism. The purpose of our investigation was to examine the bactericidal activity of LLO water against pathogenic bacteria in the medical, veterinary, and public health fields. We observed by optical microscope and electron microscope how LLO water was acted against bacterial cells. Moreover, the characteristics of LLO water were determined by carrying out dilutions and limited values.

\section{Material and Methods}

\section{Long lifetime ozone water and control water}

Long-lifetime ozone (LLO) water produced by an electrolytic system using a felt separator was described previously [2]. This electrolytic system using platinum $(\mathrm{Pt})$ mesh electrodes combined with a conventional polymer electrolyte, the Nafion 117 membrane, produced a high efficiency LLO water from tap water directly. The LLO water had a neutral $\mathrm{pH}$ (pH 5.5 to 7.0), contained high levels of hydroxyl radicals, and did not contain residual chlorine or $\mathrm{NaClO}$. Chlorhexidine (CHG, Sumitomo Pharmaceuticals co. LTD, Osaka, Japan) at a concentration of $0.05 \%$ was used as a positive control for bactericidal activity and distilled water was used as a negative control.

*Corresponding author: Kataoka Y, Department of Veterinary Microbiology, Nippon Veterinary and Life Science University, Musashino, Tokyo 180-8602 Japan, Tel: 81-42-231-4151, Fax: 042-231-4560; E-mail: ykataoka@nvlu.ac.jp

Received December 09, 2015; Accepted December 28, 2015; Published December 30, 2015

Citation: Kataoka Y, Ochi H, Sawada T, Miyakawa Y, Hatakeyama H (2015) Bactericidal and Sporicidal Activities against Pathogenic Bacteria of Direct Flow Electrolyzed Water. J Food Ind Microbiol 1: 105. doi:10.4172/2572-4134.1000105

Copyright: $\odot 2015$ Kataoka Y, et al. This is an open-access article distributed under the terms of the Creative Commons Attribution License, which permits unrestricted use, distribution, and reproduction in any medium, provided the original author and source are credited. 
Citation: Kataoka Y, Ochi H, Sawada T, Miyakawa Y, Hatakeyama H (2015) Bactericidal and Sporicidal Activities against Pathogenic Bacteria of Direct Flow Electrolyzed Water. J Food Ind Microbiol 1: 105. doi:10.4172/2572-4134.1000105

\section{Bacteria}

Escherichia coli NIHJ and S. aureus 209P were used as control strains for bactericidal tests. E. coli O157:H7 CE194, methicillinresistant S. aureus NVLU-183, P. aeruginosa ATCC27853, B. anthracis Davis, B. cereus ATCC14579, B. subtilis ATCC9372 and L. pneumophila ATCC27853 were used as the pathogenic bacteria. These bacterial strains were type strains, reference strains or were isolated from diseased animals or humans in our laboratory's bacterial collections.

\section{Bacterial cultures and preparation of bacterial suspensions}

E. coli, $S$. aureus and $P$. aeruginosa were inoculated into heart infusion broth (Becton, Dickinson and Co. USA) and cultured at $37^{\circ} \mathrm{C}$ for 18 hrs. L. pneumophila was cultured on buffered charcoal yeast extract agar (B-CYE agar; Becton, Dickinson and Co. USA) at $35^{\circ} \mathrm{C}$ for $48 \mathrm{~h}$. After incubation, L. pneumophila colonies were suspended in $0.85 \% \mathrm{NaCl}$ solution and adjusted to an optical density of 0.1 at $600 \mathrm{~nm}$ (OD600) using an ERMA AE200 spectrophotometer (ERMA Inc. Japan). B. anthracis, B. cereus and B. subtilis strains were cultured in trypticase soy broth (Becton, Dickinson and Co. USA) at $37^{\circ} \mathrm{C}$ for 18 hrs. B. anthracis, B. cereus and B. subtilis endospores were incubated overnight on heart infusion agar at $37^{\circ} \mathrm{C}$, and further incubated for 5 days at room temperature. After incubation, Bacillus colonies were suspended in $0.85 \% \mathrm{NaCl}$ solution to an OD600 of 0.1 Bacillus endospore solutions were treated at $62^{\circ} \mathrm{C}$ for $30 \mathrm{~min}$ to kill the vegetative cells.

\section{Bactericidal test procedures}

Bactericidal tests of LLO water were performed by using a modification of the procedure used to test bactericidal activity of disinfectants [12]. Two hundred $\mu \mathrm{l}$ of each bacterial suspension was mixed with $20 \mathrm{ml}$ of LLO water, $20 \mathrm{ml}$ of $0.05 \%$ chlorhexidine or $20 \mathrm{ml}$ of distilled water as controls, and the mixtures were maintained for 1 , 2, 3, 5 and $10 \mathrm{~min}$ at room temperature. One hundred $\mu \mathrm{l}$ of this mixture was taken at various time points, and $5 \mathrm{ml}$ of $0.5 \%$ sodium thiosulfate stop solution was added. The treated bacterial samples were cultured on heart infusion agar at $37^{\circ} \mathrm{C}$ for $24 \mathrm{hrs}$, except L. pneumophila, which was grown on $\mathrm{B}-\mathrm{CYE}$ agar at $35^{\circ} \mathrm{C}$ for $48 \mathrm{hrs}$. After incubation, the bactericidal activity of LLO water was determined by counting the number of bacterial colonies and comparing the CFUs with those of the samples that were treated with disinfectant and distilled water.

\section{Microscopic and electron microscopic observation of LLO water-treated bacteria}

S. aureus NVLU-183 strain was used in this study. S. aureus NVLU183 was cultured in trypticase soy broth at $37^{\circ} \mathrm{C}$ for $18 \mathrm{hrs}$, and $200 \mathrm{l}$ of each bacterial culture was mixed with $20 \mathrm{ml}$ of LLO water or $20 \mathrm{ml}$ of distilled water. Distilled water was used as a negative control. After incubating at $20^{\circ} \mathrm{C}$ for 1 second, the reaction was stopped by adding $0.5 \%$ sodium thiosulfate solution. Cells were fixed for 24 hrs with $0.2 \%$ formaldehyde in normal saline $(0.85 \% \mathrm{NaCl}$ solution). The fixed bacterial cells were washed twice by PBS and then stained with TI blue solution (Nisshin EM, Tokyo, Japan) for $2 \mathrm{~min}$ at room temperature according to the manufacturer's instructions on a nano-percolator filter (JEOL Ltd. Tokyo, Japan). The sample on the filter was mounted directly to the specimen holder and examined using a Miniscope TM-3000 scanning electron microscope (Hitachi High-Technologies Corporation, Tokyo, Japan). B. cereus ATCC14579 strain was cultured in trypticase soy broth at $37^{\circ} \mathrm{C}$ for $18 \mathrm{hrs}$, and $200 \mu \mathrm{l}$ of the bacterial culture was mixed with $20 \mathrm{ml}$ of LLO water or $20 \mathrm{ml}$ of distilled water. After incubating at $20^{\circ} \mathrm{C}$ for $10 \mathrm{sec}$, the reaction was stopped by adding
$0.5 \%$ sodium thiosulfate solution. Bacterial pellets were fixed with 2.5\% glutaraldehyde in phosphate-buffered saline. The samples were post fixed with $1 \%$ osmium tetroxide (OsO4), and dehydrated using ethanol. Subsequently, the pellets were embedded in Epon 812 (TAAB Laboratories, England), ultra-thinly sectioned, and stained with uranyl acetate and lead citrate. The samples were observed with a transmission electron microscope (JEM-1011; JEOL Ltd. Tokyo, Japan).

\section{Determination of the limits of bactericidal activity of LLO water}

To determine whether LLO water was active with higher concentrations of cells, how long the LLO water retained bactericidal activity, bactericidal tests were carried out with more concentrated cell suspensions, with LLO water that had been left at room temperature. Suspensions of E. coli and S. aureus overnight cultures were adjusted to approximately $10^{7}$ to $10^{8} \mathrm{CFU} / \mathrm{ml}$. Bacterial solutions were diluted from 2 to 8 -fold with $0.85 \% \mathrm{NaCl}$. Bctericidal test was performed as described above and distilled water was used as the negative control. LLO water was produced by the electrolytic system and left at room temperature for 3, 6 and $24 \mathrm{hrs}$. The bactericidal activity of the LLO water was examined to determine whether it retained antibacterial capability using E. coli.

\section{Statistical analysis}

The bactericidal and sporicidal activities of LLO water were determined with 3 replications. Statistical significance was determined by chi-square analysis, and $\mathrm{P}<0.05$ was considered significant.

\section{Results and Discussion}

\section{Bactericidal activity of LLO water}

Results of studies examining the bactericidal activity of LLO water are shown in Table 1. In the case of $7.059 \pm 0.0567 \log _{10}$ CFU E. coli $\mathrm{NIHJ}$ strain, $20 \mathrm{ml}$ of LLO water killed to below the detection limit within one min same as $0.05 \%$ CHG. In contrast, distilled water is the negative control; the same number of inoculum bacterial cells has been detected. In the pathogenic bacteria, LLO water killed $7.144 \pm 0.0507$ $\log _{10}$ CFU of E. coli O157:H7, $6.979 \pm 0.0450 \log _{10}$ CFU of MRSA, 6.503 $\pm 0.3681 \log _{10}$ CFU of $P$. aeruginosa and $6.579 \pm 0.1230 \log _{10}$ CFU of L. pneumophila within one minute. Furthermore, $6.898 \pm 0.0811 \log _{10}$ CFU of vegetative cells of $B$. anthracis, $6.0710 \pm 1605 \log _{10}$ CFU of $B$. cereus and $5.675 \pm 0.1408 \log _{10}$ CFU of $B$. subtilis were killed within one minute (Table 1). In contrast, endospores of $5.679 \pm 0.1155 \log _{10}$ CFU of $B$. anthracis were killed within $20 \mathrm{~min}$ (Table 2). The positive control, $0.05 \%$ chlorhexidine, also killed all tested bacteria except B. anthracis spores within one minute. On the other hand, use of distilled water as the negative control resulted in the detection of the same number of cells as the inoculum at each treatment time (Table 1).

\section{Electron microscopic observation of bacterial cells treated with LLO water}

Figure $1 \mathrm{a}$ and $1 \mathrm{~b}$ shows electron micrographs of $S$. aureus cells after treatment with LLO water. As shown in Figure 1a (untreated) and Figure $1 \mathrm{~b}$ (treated with LLO water), the morphological changes in the $S$. aureus cells are clearly evident. Bacterial cells of $S$. aureus treated with LLO water were expanded by 3 to 5 -fold, and further cell ambient had changed from spherical form to irregular morphology. Therefore, LLO water directly damaged the bacterial cell walls.

The TEM images of the $B$. cereus cells showed notable changes to their cell wall after treatment with LLO water (Figure $2 a$ and $2 b$ ). The 
Citation: Kataoka Y, Ochi H, Sawada T, Miyakawa Y, Hatakeyama H (2015) Bactericidal and Sporicidal Activities against Pathogenic Bacteria of Direct Flow Electrolyzed Water. J Food Ind Microbiol 1: 105. doi:10.4172/2572-4134.1000105

Page 3 of 6

\begin{tabular}{|c|c|c|c|c|c|c|c|c|}
\hline \multirow{2}{*}{ Bacterial strain } & \multirow{2}{*}{ Test water } & \multirow{2}{*}{$\begin{array}{l}\text { The value of } \\
\operatorname{ORP}(\mathrm{mV})\end{array}$} & \multirow{2}{*}{$\begin{array}{l}\text { Inoculated cells } \\
\text { (Log } \pm \text { SD) }\end{array}$} & \multicolumn{5}{|c|}{ Cells $(\log \pm \mathrm{SD})$ remaining following reaction time $(\mathrm{min})$ of : } \\
\hline & & & & 1 & 2 & 3 & 5 & 10 \\
\hline \multirow{3}{*}{ E. coli $\mathrm{NIHJ}$} & LLO water & $974 \pm 12.49^{a}$ & \multirow{3}{*}{$7.059 \pm 00567$} & $<2.301^{*}$ & $<2.301^{*}$ & $<2.301^{*}$ & $<2.301^{*}$ & $<2.301^{*}$ \\
\hline & $0.05 \% \mathrm{CHG}$ & $364.3 \pm 4.51$ & & $<2.301^{*}$ & $<2.301^{*}$ & $<2.301^{*}$ & $<2.301^{*}$ & $<2.301^{*}$ \\
\hline & $\begin{array}{l}\text { Sterile distilled } \\
\text { water }\end{array}$ & $259.7 \pm 1.53$ & & $7.364 \pm 0.0753$ & $7.321 \pm 0.0415$ & $7.343 \pm 0.1247$ & $7.365 \pm 0.0652$ & $7.322 \pm 0.1819$ \\
\hline \multirow{3}{*}{ E. coli 0157:H7 CE194 } & LLO water & $979 \pm 20.67$ & \multirow{3}{*}{$7.144 \pm 0.0507$} & $<2.301^{*}$ & $<2.301^{*}$ & $<2.301^{*}$ & $<2.301^{*}$ & $<2.301^{*}$ \\
\hline & $0.05 \% \mathrm{CHG}$ & $359 \pm 7.55$ & & $<2.301^{*}$ & $<2.301^{*}$ & $<2.301^{*}$ & $<2.301^{*}$ & $<2.301^{*}$ \\
\hline & $\begin{array}{l}\text { Sterile distilled } \\
\text { water }\end{array}$ & $264.3 \pm 6.51$ & & $7.206 \pm 0.1467$ & $7.144 \pm 0.052$ & $7.223 \pm 0.1393$ & $7.244 \pm 0.0632$ & $7.111 \pm 0.1307$ \\
\hline \multirow{3}{*}{ S. aureus 209P } & LLO water & $969.7 \pm 9.07$ & \multirow{3}{*}{$6.966 \pm 0.0375$} & $5.1 \pm 0.1384$ & $<2.301^{*}$ & $<2.301^{*}$ & $<2.301^{*}$ & $<2.301^{*}$ \\
\hline & $0.05 \% \mathrm{CHG}$ & $355.3 \pm 13.31$ & & $<2.301^{*}$ & $<2.301^{*}$ & $<2.301^{*}$ & $<2.301^{*}$ & $<2.301^{*}$ \\
\hline & $\begin{array}{l}\text { Sterile distilled } \\
\text { water }\end{array}$ & $259 \pm 1.00$ & & $6.392 \pm 0.1229$ & $6.417 \pm 0.1095$ & $6.522 \pm 0.1093$ & $6.604 \pm 0.0485$ & $6.581 \pm 0.1985$ \\
\hline \multirow{3}{*}{$\begin{array}{l}\text { Methicillin-resistant } S \text {. } \\
\text { aureus NVLU-183 }\end{array}$} & LLO water & $979 \pm 23.00$ & \multirow{3}{*}{$6.979 \pm 0.045$} & $<2.301^{*}$ & $<2.301^{*}$ & $<2.301^{*}$ & $<2.301^{*}$ & $<2.301^{*}$ \\
\hline & $0.05 \% \mathrm{CHG}$ & $360 \pm 3.21$ & & $<2.301^{*}$ & $<2.301^{*}$ & $<2.301^{*}$ & $<2.301^{*}$ & $<2.301^{*}$ \\
\hline & $\begin{array}{l}\text { Sterile distilled } \\
\text { water }\end{array}$ & $269 \pm 10.15$ & & $6.662 \pm 0.0959$ & $6.8 \pm 0.141$ & $6.725 \pm 0.0557$ & $6.612 \pm 0.3134$ & $6.728 \pm 0.1131$ \\
\hline \multirow{3}{*}{ P. aeruginosa ATCC 27853} & LLO water & $957 \pm 9.54$ & \multirow{3}{*}{$6.503 \pm 0.3681$} & $<2.301^{*}$ & $<2.301^{*}$ & $<2.301^{*}$ & $<2.301^{*}$ & $<2.301^{*}$ \\
\hline & $0.05 \% \mathrm{CHG}$ & $346.7 \pm 11.06$ & & $<2.301^{*}$ & $<2.301^{*}$ & $<2.301^{*}$ & $<2.301^{*}$ & $<2.301^{*}$ \\
\hline & $\begin{array}{l}\text { Sterile distilled } \\
\text { water }\end{array}$ & $257.7 \pm 6.81$ & & $6.930 \pm 0.1134$ & $6.911 \pm 0.1661$ & $6.712 \pm 0.3403$ & $6.968 \pm 0.0720$ & $6.924 \pm 0.0889$ \\
\hline \multirow{3}{*}{$\begin{array}{l}\text { L. pneumophila } \\
\text { ATCC27853 }\end{array}$} & LLO water & $989.7 \pm 13.58$ & \multirow{3}{*}{$6.579 \pm 0.123$} & $<2.301^{*}$ & $<2.301^{*}$ & $<2.301^{*}$ & $<2.301^{*}$ & $<2.301^{*}$ \\
\hline & $0.05 \% \mathrm{CHG}$ & $355.3 \pm 4.51$ & & $<2.301^{*}$ & $<2.301^{*}$ & $<2.301^{*}$ & $<2.301^{*}$ & $<2.301^{*}$ \\
\hline & $\begin{array}{l}\text { Sterile distilled } \\
\text { water }\end{array}$ & $273.7 \pm 9.61$ & & $6.199 \pm 0.1780$ & $6.073 \pm 0.1589$ & $5.876 \pm 0.1478$ & $6.039 \pm 0.1084$ & $6.283 \pm 0.1149$ \\
\hline \multirow{3}{*}{$\begin{array}{l}\text { Vegetative cells of } B \text {. } \\
\text { anthracis Davis }\end{array}$} & LLO water & $985.7 a \pm 14.64$ & \multirow{3}{*}{$6.898 \pm 0.0811$} & $<2.301^{*}$ & $<2.301^{*}$ & $<2.301^{*}$ & $<2.301^{*}$ & $<2.301^{*}$ \\
\hline & $0.05 \% \mathrm{CHG}$ & $352.7 \pm 11.37$ & & $2.300 \pm 0.001^{*}$ & $<2.301^{*}$ & $2.229 \pm 0.001^{*}$ & $<2.301^{*}$ & $<2.301^{*}$ \\
\hline & $\begin{array}{l}\text { Sterile distilled } \\
\text { water }\end{array}$ & $252.3 \pm 11.59$ & & $6.631 \pm 0.2039$ & $6.590 \pm 0.2603$ & $6.686 \pm 0.0953$ & $6.641 \pm 0.0596$ & $6.564 \pm 0.1034$ \\
\hline \multirow{3}{*}{$\begin{array}{l}\text { Vegetative cells of } B \text {. } \\
\text { cereus ATCC14579 }\end{array}$} & LLO water & $981.7 \pm 10.4$ & \multirow{3}{*}{$6.071 \pm 0.1605$} & $<2.301^{*}$ & $<2.301^{*}$ & $<2.301^{*}$ & $<2.301^{*}$ & $<2.301^{*}$ \\
\hline & $0.05 \% \mathrm{CHG}$ & $362.7 \pm 3.06$ & & $<2.301^{*}$ & $<2.301^{*}$ & $<2.301^{*}$ & $<2.301^{*}$ & $<2.301^{*}$ \\
\hline & $\begin{array}{l}\text { Sterile distilled } \\
\text { water }\end{array}$ & $257.3 \pm 3.06$ & & $6.539 \pm 0.1786$ & $6.371 \pm 0.1622$ & $6.221 \pm 0.1512$ & $6.212 \pm 0.1171$ & $6.375 \pm 0.1899$ \\
\hline \multirow{2}{*}{$\begin{array}{l}\text { Vegetative cells of } B \text {. } \\
\text { subtilis ATCC9372 }\end{array}$} & LLO water & $977.3 \pm 25.11$ & \multirow{2}{*}{$5.675 \pm 0.1408$} & $2.301^{*}$ & $<2.301^{*}$ & $<2.301^{*}$ & $<2.301^{*}$ & $<2.301^{*}$ \\
\hline & $\begin{array}{l}\text { Sterile distilled } \\
\text { water }\end{array}$ & $255.7 \pm 6.66$ & & $6.419 \pm 0.1871$ & $6.348 \pm 0.2945$ & $6.455 \pm 0.1639$ & $6.212 \pm 0.1938$ & $6.675 \pm 0.0865$ \\
\hline
\end{tabular}

Table 1: Bactericidal activities of LLO water against Escherichia coli, Staphylococcus aureus, Bacillus anthracis, B. cereus, B. subtilis, Pseudomonas aeruginosa and Legionella pneumophila.

bactericidal effect of LLO water was shown to destroy the structure of the cell wall of bacterial cells. In addition to this, the viable cell count revealed that LLO water was an effective treatment against the survival of bacterial cells.

\section{Limits of bactericidal activity of LLO water}

Although LLO water killed $6.0792 \log _{10}$ CFU of E. coli, $6.3617 \log _{10}$ CFU remained viable. Similarly, $8.1461 \log _{10}$ CFU of $S$. aureus were viable even though LLO killed $7.5441 \log _{10}$ CFU (Table 3).

After LLO water was left at room temperature for 3, 6, $24 \mathrm{hrs,} \mathrm{the}$ oxidation-reduction potential (ORP) value was maintained at 950 for over for six hrs, and $7.5185 \log _{10}$ CFU of E. coli were killed by $6 \mathrm{hr}$ old LLO water (Table 4).

\section{Discussion}

LLO water, which was produced from tap water, was shown to work as well as bactericidal disinfectants against various pathogenic bacteria found in medical and public health settings. In addition, LLO water had bactericidal activity against endospores of $B$. anthracis, which have been used as an agent of biological terrorism in recent years. Based on these findings, LLO water may be widely applicable in food hygiene, medicine and veterinary medicine as functional water. The characteristics of LLO water include a neutral $\mathrm{pH}$, the same ion concentration as tap water, no sodium hypochlorite, $>0 \%$ ozone concentration, and a lifetime $>150 \mathrm{hrs}$ [2]. In contrast, acidic electrolyzed water has a $\mathrm{pH}$ of 2 to 3 , and an active chlorine content of 10 to $90 \mathrm{ppm}$; basic electrolyzed water has a $\mathrm{pH}$ of 10 to 13 and 
Citation: Kataoka Y, Ochi H, Sawada T, Miyakawa Y, Hatakeyama H (2015) Bactericidal and Sporicidal Activities against Pathogenic Bacteria of Direct Flow Electrolyzed Water. J Food Ind Microbiol 1: 105. doi:10.4172/2572-4134.1000105

Page 4 of 6

\begin{tabular}{|c|c|c|c|c|c|c|c|}
\hline \multirow{2}{*}{ Test water } & \multirow{2}{*}{$\begin{array}{l}\text { The value of ORP } \\
(\mathrm{mV})\end{array}$} & \multirow{2}{*}{$\begin{array}{l}\text { Inoculated cells } \\
\text { (Log } \pm S D)\end{array}$} & \multicolumn{5}{|c|}{ Cells $(\log \pm S D)$ remaining following reaction time $(\mathrm{min})$ of : } \\
\hline & & & 1 & 3 & 5 & 10 & 20 \\
\hline LLO water & $987 \pm 13.53^{a}$ & \multirow{2}{*}{$5.679 \pm 0.1155$} & $3.094 \pm 0.1029^{*}$ & $3.314 \pm 0.0216^{*}$ & $2.835 \pm 0.6811^{*}$ & $2.602 \pm 0.301^{*}$ & $<2.301^{*}$ \\
\hline Sterile distilled water & $259 \pm 7.00$ & & $5.628 \pm 0.1384$ & $5.413 \pm 0.1756$ & $5.502 \pm 0.1738$ & $5.621 \pm 0.0533$ & $5.528 \pm 0.0655$ \\
\hline
\end{tabular}

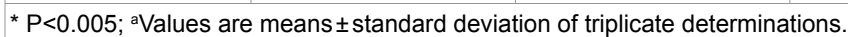

Table 2: Bactericidal activity of LLO water against spores of Bacillus anthracis Davis.

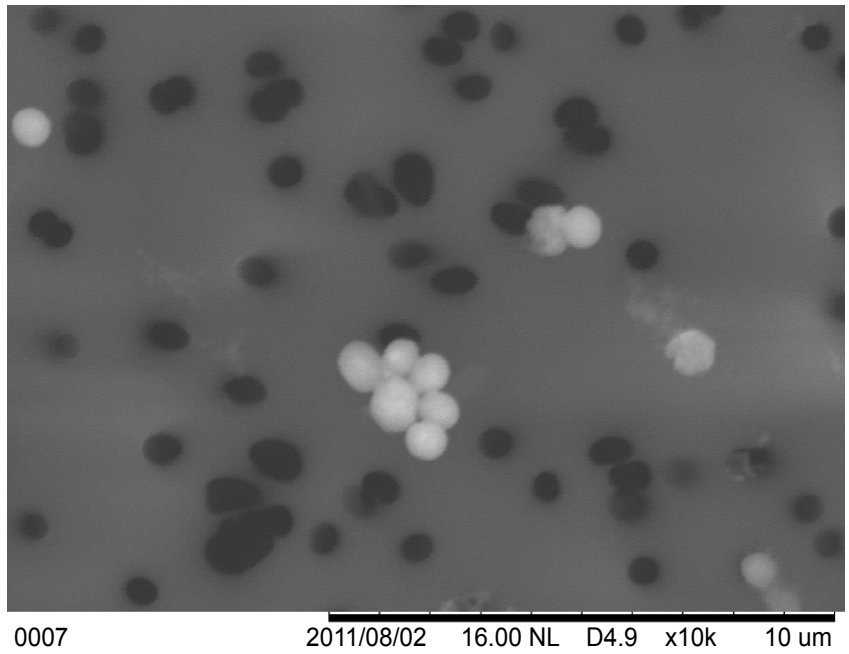

Figure 1a: A scanning electron microscopic observation with the bacteriocidal activity of LLO water (TI blue stain, Staphylococcus aureus $\times 10,000)$ shows $S$ aureus 209P strain as control.

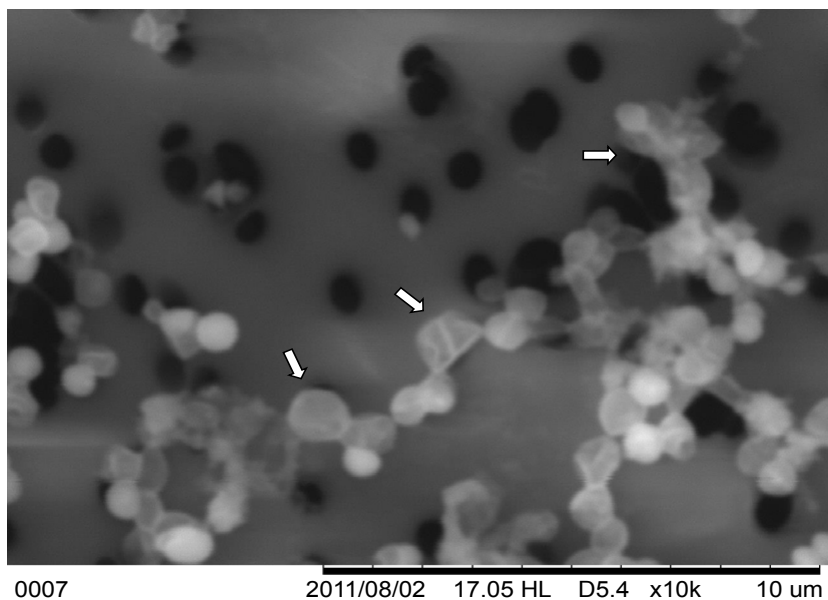

Figure 1b: A scanning electron microscopic observation with the bacteriocidal activity of LLO water (TI blue stain, Staphylococcus aureus $\times 10,000)$ shows $S$ aureus treated with LLO water.

an oxidation-reduction potential of -800 to $-900 \mathrm{mV}$ [1]. However, acidic electrolyzed water and basic electrolyzed water show a high potential for application in the agriculture and food industries as an environmentally friendly disinfection agent. Thus, LLO water is not limited to industrial applications such as agriculture and food; a wide range of applications could be expected in fields including medical and veterinary medicine, and food hygiene.

In addition to the $\mathrm{pH}$ of LLO water, the ORP values should also be taken into consideration. This ORP can be used as an indicator of the ability of electrolyzed water to oxidize or reduce compounds in the bacterial cell wall. The corresponding high ORP has been associated with the strong bactericidal activity of Electrolyzed water [13]. Solutions with high ORP values can induce modifications to bacterial membranes by causing changes to the cell's electron flow [14]. In this study, the ORP values of the LLO water was about $+1000 \mathrm{mV}$, and had been maintained for $6 \mathrm{hrs}$. Therefore, it was revealed that the bactericidal activities of LLO water had been at least 6 hrs could be kept.

When the effect on the bacteria was observed using electron microscopy, LLO water was found to destroy bacterial cell walls. This observation suggested that free radicals are produced from ozone, which is the main component of LLO water, and cell wall damage was caused by free radicals, resulting in cell lysis in response to the osmotic pressure. In contrast, acidic electrolyzed water produced from a dilute sodium chloride solution has a similar bactericidal effect as 
Citation: Kataoka Y, Ochi H, Sawada T, Miyakawa Y, Hatakeyama H (2015) Bactericidal and Sporicidal Activities against Pathogenic Bacteria of Direct Flow Electrolyzed Water. J Food Ind Microbiol 1: 105. doi:10.4172/2572-4134.1000105

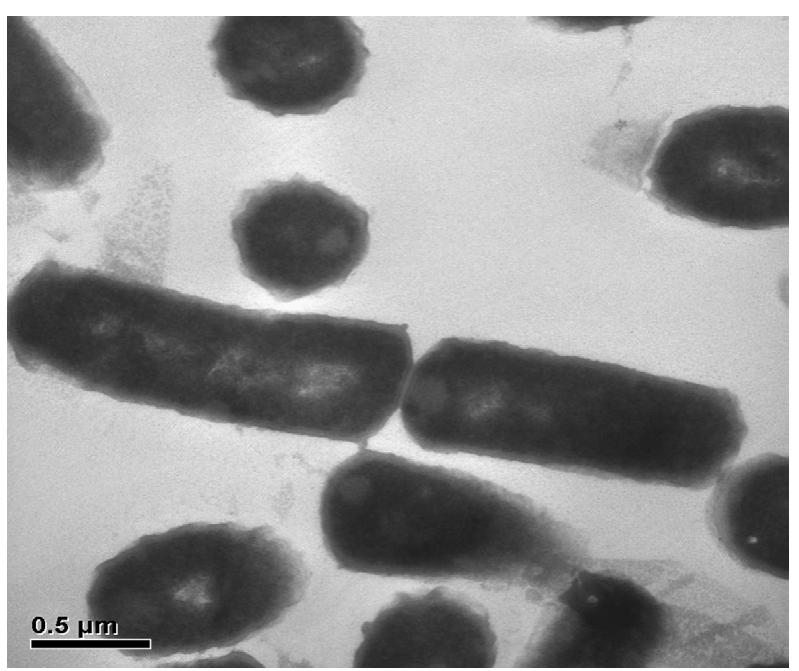

Figure 2a: A transmission electron microscopic observation with the bacteriocidal activity of LLO water (stain, Bacillus cereus $\times 10,000)$ shows B. ceureus ATCC14579 strain as control.

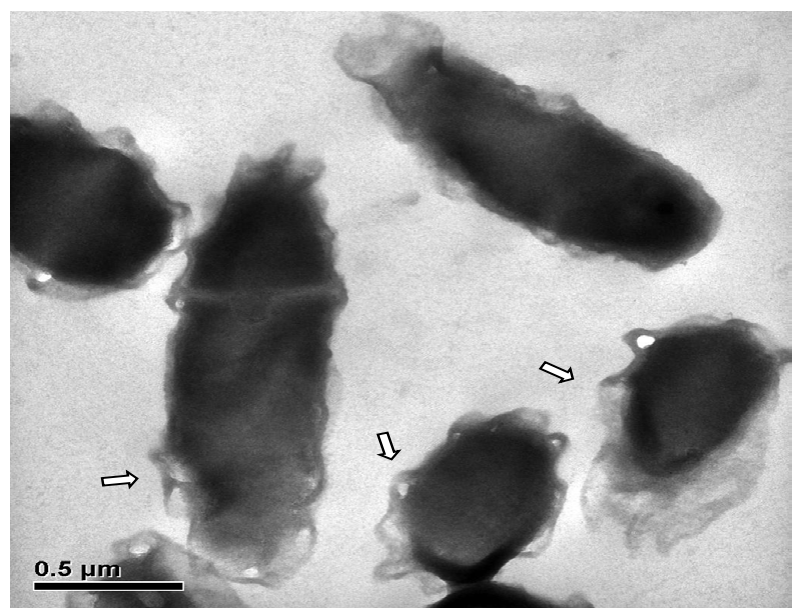

Figure 2b: A transmission electron microscopic observation with the bacteriocidal activity of LLO water (stain, Bacillus cereus $\times 10,000$ ) shows $B$. ceureus treated with LLO water.

\begin{tabular}{|c|c|c|c|c|c|c|}
\hline \multirow{2}{*}{ Bacteria } & \multirow{2}{*}{ Test water } & \multirow{2}{*}{ The value of ORP $(\mathrm{mV})$} & \multirow{2}{*}{ Inoculated cells (Log) } & \multicolumn{3}{|c|}{ Cells (Log) remaining following reaction time $(\min )$ of } \\
\hline & & & & 1 & 5 & 10 \\
\hline \multirow{5}{*}{ E. coli } & \multirow{4}{*}{ LLO water } & \multirow{4}{*}{1007} & 6.3617 & 5.9243 & 5.9912 & 6.017 \\
\hline & & & 6.0792 & $<2.301^{*}$ & $<2.301^{*}$ & $<2.301^{*}$ \\
\hline & & & 5.8129 & $<2.301^{*}$ & $<2.301^{*}$ & $<2.301^{*}$ \\
\hline & & & 5.5051 & $<2.301^{*}$ & $<2.301^{*}$ & $<2.301^{*}$ \\
\hline & Sterile distilled water & 215 & 7.3617 & 7.2041 & 7.2041 & 7.2304 \\
\hline \multirow{5}{*}{ S. aureus } & \multirow{4}{*}{ LLO water } & \multirow{4}{*}{1003} & 8.1461 & 7.8195 & 7.6434 & 7.5797 \\
\hline & & & 7.845 & 6.6334 & 6.7242 & 6.716 \\
\hline & & & 7.5441 & $<2.301^{*}$ & $<2.301^{*}$ & $<2.301^{*}$ \\
\hline & & & 7.2552 & $<2.301^{*}$ & $<2.301^{*}$ & $<2.301^{*}$ \\
\hline & Sterile distilled water & 216 & 7.1461 & 7.0791 & 6.8451 & 7.0414 \\
\hline
\end{tabular}

Table 3: The limit value of bactericidal activity of LLO water against Escherichia coli NIHJ and Staphylococcus aureus 209P. 
Citation: Kataoka Y, Ochi H, Sawada T, Miyakawa Y, Hatakeyama H (2015) Bactericidal and Sporicidal Activities against Pathogenic Bacteria of Direct Flow Electrolyzed Water. J Food Ind Microbiol 1: 105. doi:10.4172/2572-4134.1000105

Page 6 of 6

\begin{tabular}{|c|c|c|c|c|c|}
\hline \multirow{2}{*}{ Test water } & \multirow{2}{*}{ Inoculated cells (Log) } & \multicolumn{4}{|c|}{ Cells (Log) remaining following LLO water incubation time (hrs) of : } \\
\hline & & 0 & 3 & 6 & 24 \\
\hline LLO water & \multirow{2}{*}{7.5185} & $<2.301^{*}$ & $<2.301^{*}$ & $<2.301^{*}$ & 6.7993 \\
\hline The value of ORP $(\mathrm{mV})$ & & 1014 & 974 & 958 & 620 \\
\hline Sterile distilled water & 7.5185 & 7.4314 & 7.4149 & 7.2553 & 7.3424 \\
\hline
\end{tabular}

Table 4: Bactericidal activity of LLO water after collection against Escherichia coli NIHJ.

the disinfectant sodium hypochlorite [15]. Therefore, it is clear that the bactericidal effect of LLO water is due to the ozone and radicals generated by electrolysis of tap water.

In our current study, we have demonstrated the bactericidal and sporicidal activities of LLO water. The effect of LLO water as a disinfectant is attenuated by incorporation of organic matter, which is similar to findings with disinfectants. However, the fact that inactivated LLO water becomes mere water would allow its use in a wide range of applications without the possibility of polluting the environment. In the future, we will explore additional applications of LLO water.

\section{References}

1. Hricova D, Stephan R, Zweifel C (2008) Electrolyzed water and its application in the food industry. J Food Prot 71: 1934-1947.

2. Okada F, Naya K (2009) Highly efficient and long-lifetime ozone water production system realized using a felt separator. J Electrochem Soci 156: E125-E131.

3. Kim JG, Yousef AE, Dave S (1999) Application of ozone for enhancing the microbiological safety and quality of foods: A review. J Food Prot 62: 10711087.

4. Arita M, Nagayoshi M, Fukuizumi T, Okinaga T, Masumi S (2005) Microbicidal efficacy of ozonated water against Candida albicans adhering to acrylic denture plates. Oral Microbiol Immunol 20: 206-210.

5. Perrine D, Georges P, Langlais B (1990) The efficacy of water ozonation on the inactivation of oocysts of Cryptosporidium. Bull Acad Natl Med 174: 845-851.

6. Rickloff JR (1987) An evaluation of the sporicidal activity of ozone. Appl Environ Microbiol 53: 683-686.
7. Ito T, Okuma K, Ma XX, Yuzawa H, Hiramatsu K (2003) Insights on antibiotic resistance of Staphylococcus aureus from its whole genome: genomic island SCC. Drug Resist Updates 6: 41-52.

8. Sasaki M, Hiyama E, Takesue Y, Kodaira M, Sueda T (2004) Clinical surveillance of surgical imipenem-resistant Pseudomonas aeruginosa infection in a Japanese hospital. J Hosp Infect 56: 111-118.

9. Torii K, linuma Y, Ichikawa M, Kato K, Koide M, et al. (2003) A case of nosocomial Legionella pneumophila pneumonia. Jpn J Infect Dis 56: 101-102.

10. Imperiale MJ, Casadevall A (2011) Bioterrorism: Lessons learned since the anthrax mailings. mBio 2: e00232-11.

11. Stevenson SML, Cook SR, Bach SJ, McAllister TA (2004) Effects of water source, dilution, storage, and bacterial and fecal loads on the efficacy of electrolyzed oxidizing water for the control of Escherichia coli 0157:H7. J Food Prot 67: 1377-1383.

12. Berkelman RL, Holland BW, Anderson RL (1982) Increased bactericidal activity of dilute preparations of povidone-iodine solutions. J Clin Microbiol 15: 635639.

13. Kim C, Hung YC, Brackett RE (2000) Roles of oxidation-reduction potential in electrolyzed oxidizing and chemically modified water for the inactivation of food-related pathogens. J Food Prot 63: 19-24.

14. Park H, Hung Y, Chung D (2004) Effects of chlorine and $\mathrm{pH}$ on efficacy of electrolyzed water for inactivating Escherichia coli $\mathrm{O} 157: \mathrm{H} 7$ and Listeria monocytogenes. Int J Food Microbiol 91: 13-18.

15. Vandekinderen I, Van Camp J, De Meulenaer B, Veramme K, Bernaert N (2009) Moderate and high doses of sodium hypochlorite, neutral electrolyzed oxidizing water, peroxyacetic acid, and gaseous chlorine dioxide did not affect the nutritional and sensory qualities of fresh-cut Iceberg lettuce (Lactuca sativa Var capitata L) after washing. J Agric Food Chem 57: 4195-4203. 